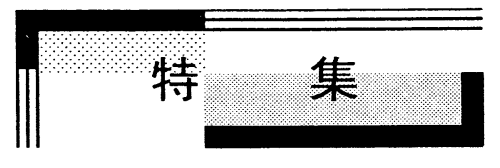

\title{
原子カ施設解体におけるエアロゾル粒子の飛散挙動 *
}

\author{
Aerosol Behaviors in Dismantling of Nuclear Facilities \\ 島田太郎** 立 花光夫** 柳 原 敏** \\ SHIMADA Taro TACHIBANA Mitsuo YANAGIHARA Satoshi
}

\begin{abstract}
Radioactive aerosols produced by cutting components and structures may cause internal exposures of workers and secondary contamination in dismantling nuclear facilities. It must be important for safety to understand the diffusion behaviors of aerosols in dismantling activities under various working conditions. Therefore diffusion behaviors of aerosols have been studied by experiments such as flow visualization and by numerical analyses based on the fluid dynamics. The results were compared with those obtained in the analyses. As a result, it was confirmed that the diffusion behaviors of aerosols in in-air plasma arc cutting can be simulated by numerical analyses.
\end{abstract}

Keywords : Decommissioning, Dismantlement of Nuclear Facilities, Radioactive Aerosol, Flow Visualization

1. はじめに

原子力発電所の寿命は、現在長寿命化の検討 がされているが、一般に 30 ないし 40 年と見込 まれている。超寿命化が行われない場合、2010 年頃には現在稼働中の原子力発電所のいくつか が運転を停止し、相次いで廃止措置が行われる と予想されている。この状況の中、1996 年 3 月 には、試験研究施設ながら我が国初の原子力発 電プラントである日本原子力研究所の動力試験 炉(JPDR)解体実地試験が終了し、原子力発電所 の安全な解体が可能であることが実証された [1]。現在、解体実地試験で得られた数多くの知 見に基づいて、解体技術の商業用原子力発電所 への適用性について検討を進めている。
そして、1998 年 3 月、日本原子力発電東海発 電所がその運転を永久に停止し、商業用原子力 発電所の廃止措置へ向けた第一歩を踏み始めた。 我が国では、狭㿽な国土を鑑み早急に解体撤去 することを方針としており、当該発電所でも解 体準備が進められている[2]。

原子力施設の解体においては、解体対象物が 放射能を保有しているため、放射線下での作業 が必要となる。遠隔操作による解体技術の適用 が考えられているが、線量当量率の極めて高い 環境での作業に限られ、すべての機器・構造物 を対象とすることは困難である。安全な作業環 境が整っていれば、作業効率の観点からも作業 員の手動による解体作業に頼るところは大きい

*1999.11.1 受付

** 日本原子力研究所 バックエンド技術部 † 319-1195 茨城県那珂郡東海村白方白根 2-4 TEL(029)282-6117 FAX (029)282-5446 
と予想される。作業員の安全を確保するために 安全評価手法を確立することが必要であり、原 研では、解体作業時の安全性を周辺公衆への影 響まで含めて、総合的に評価するための検討を 行っている。

解体作業のうち重要作業の一つである切断作 業においては、切断等によってドロスや切り粉 等の副次生成物が生成される。特に気中切断の 場合には放射性エアロゾル粒子が作業環境中に 飛散し、作業員の内部被ばく及び放射能污染拡 大の原因となる。つまり、解体作業を安全かつ 効率的に進めるためには、空気中放射能濃度を 合理的に達成可能な低いレベルに抑えることが 重要であり、作業環境中に放出されるエアロゾ ル粒子の飛散挙動を把握して、効率的にそれら を排出する必要がある。

そこで、解体作業におけるエアロゾル粒子の 飛散挙動評価を数值解析により行っている[3,4]。 このような環境でのエアロゾル粒子の飛散挙動 が解析できるようになれば、安全性評価上重要 な空気中放射能濃度の評価だけでなく、効率的 にエアロゾル粒子を排出できる局所排気装置を 含めた作業環境の構築にも活用が可能となる。 飛散挙動の数值解析では、主にプラズマアーク 切断を対象に、熱流体方程式と質量粒子の運動 方程式を用い、固気二相流として評価した。

さらに、解析結果を検証するため、実際に切 断試験を行い、発生する上昇流を可視化手法を 用いて観察するとともに、体系内の温度分布変 化を測定して、解析結果と比較した。

本稿では、エアロゾル粒子の飛散挙動に関し て、JPDR 解体実地試験からの知見と数值解析 及び検証実験結果の一例を紹介する。

\section{JPDR 解体実地試験におけるエアロゾル評価 \\ 2.1 解体作業の概要}

JPDR は試験研究用の沸騰水型原子力発電所 であり、後に改良を加え、最終的には $90 \mathrm{MW}$ の熱出力を有していた。構成材料は主に炭素鋼、 ステンレス鋼の金属、建屋構造物であるコンク リートである。解体作業は原子炉本体及び冷却 系配管、中性子によって放射化した原子炉周囲 のコンクリート等、さらに、污染された放射能 を有する部分をすべて取り除き、放射性物質が 残存していないことを測定によって確認して
管理区域を解除した後、建屋の解体が行われた。 放射能を有する部分に適用された解体工法は、 鋼構造物に対しては熱的 (プラズマアーク切断、 ガス切断）及び機械的切断、コンクリートに対 しては機械的切断、制御爆破が主であった。

解体作業は通常、放射性エアロゾル粒子の浮 遊空間を制限して污染拡大を防止するために、 塩化ビニール製のシートで作られたグリーンハ ウス内で行われた。グリーンハウスは常に排気 され内部は負圧を保持しており、一部が損傷し 壁が貫通した場合でも空気は外部から内部へ流 れるため、内部の放射性物質が外部に漏洩する ことはない。グリーンハウス内部のエアロゾル 粒子を含む空気は、HEPA フィルタを通過しエ アロゾル粒子を捕集した後外部に放出される。

また、切断中グリーンハウス全体にエアロゾ ル粒子が飛散する前に吸入して外部に排出する 局所排気装置を切断部近傍に設け、空気中放射 能濃度の低減を図る場合もあった。

\section{2 切断によって発生するエアロゾルの性状}

解体作業時には切断や爆破によってドロス、 切り粉、エアロゾル粒子等の副次生成物が発生 する。熱的切断時に発生する粒子径の大きいド ロスは空気中には飛散せず、直ちに落下する。 その後回収する必要があるが、作業員への内部 被ばくの影響はほとんどなく、廃棄物としての 処理も比較的容易である。ところが、比較的粒 子径の小さいエアロゾル粒子は、前述のように 作業環境中に飛散することによって作業員の内 部被ばくの原因となるとともに、放射能污染の 拡大を誘発することから、解体実地試験におい てもエアロゾル粒子の性状を調查した[5]。プラ ズマアーク切断及び機械的切断によって発生す るエアロゾル粒子の粒子径、粒径分布及び切断 溝に占める飛散粒子量の割合を表す飛散率を Table 1 に示す。飛散率はプラズマアーク切断 の場合は放射能基準、機械的切断の場合は重量 基準で測定されたものである。プラズマアーク

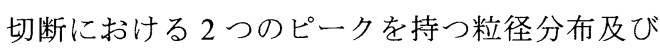
比較的大きな飛散率が特徴であった。

\section{3. エアロゾル粒子飛散挙動に関する実験方法}

実験体系を Fig.1 に示す。グリーンハウスは 透明なアクリル製で、中には排気口、吸気口、 
Table 1 Characteristics of Aerosols Produced by Cuttings

\begin{tabular}{lcc}
\hline Cutting method & Plasma arc & Mechanical \\
\hline Peak particle size & $0.3,2 \mu \mathrm{m}$ & $5 \mu \mathrm{m}$ \\
Distribution & Bimodal & Singlemodal \\
$\begin{array}{l}\text { Dispersion ratio } \\
\text { (Measurement) }\end{array}$ & $10^{-3}$ & $10^{-4}$ \\
(Activity) & (Weight) \\
\hline
\end{tabular}

被切断物、切断トーチを配置した。実験では駆 動装置に取り付けられた切断トーチが一定の速 度で移動して、厚さ $12 \mathrm{~mm}$ の炭素鋼平板を切断 した。

本実験においては、切断中及び切断後の短時 間のエアロゾル粒子の飛散挙動を把握するため、 実際にグリーン八ウス内においてプラズマアー ク切断を行い、その挙動を可視化により観測す ることを試みた。可視化手法としてレーザーラ イトシート法を採用し、可視化光源として Ar

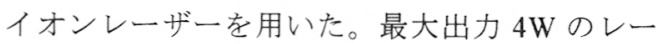
ザー発振器からのビームを光ケーブルを通して レーザーライトシートプロジェクタに通過させ、 平面状に変換し、グリーンハウスに照射した。 これによりグリーンハウスの一断面の観察が可
能となる。しかし、切断対象物と切断トーチの 間に発生する強度のアーク光が、レーザーライ 卜の光強度を上回り、切断中の可視化は困難で あり、可視化はアーク光の消滅する切断後に行 う必要があった。さらに、切断によって発生す るエアロゾル粒子だけでは、十分な可視化画像 が得られないことから、切断中及び切断後の短 時間においてはエアロゾル粒子の運動は気相の 流れのみに支配されるという仮定をおき、熱供 給によって発生する上昇流の経路を観測するた め、次の試験手順を設定した。

切断直前に $3.6 \mathrm{~m}^{3} / \mathrm{min}$ で排気されているグリ ーン八ウス内に粒子径 $1 \mu \mathrm{m}$ のトレーサーを吸 気口から導入し充満させた後に切断を開始する。 切断終了直後アークが消滅し、レーザーライト シートによる散乱光で断面を観察する。これを 切断時間を変化させて数度繰り返し、切断直後 の可視化画像を切断時間順に並べることによっ て上昇流空間分布の時間変化が取得可能となる。 あわせて、グリーン八ウス内温度分布測定を行 った。Fig. 2 に熱電対の設置位置を示寸。測定 点数は 45 とし、 $5 \mathrm{~Hz}$ で温度分布の時間変化を記 録した。切断前のグリーン八ウス内温度は $296 \mathrm{~K}$ で均一であった。

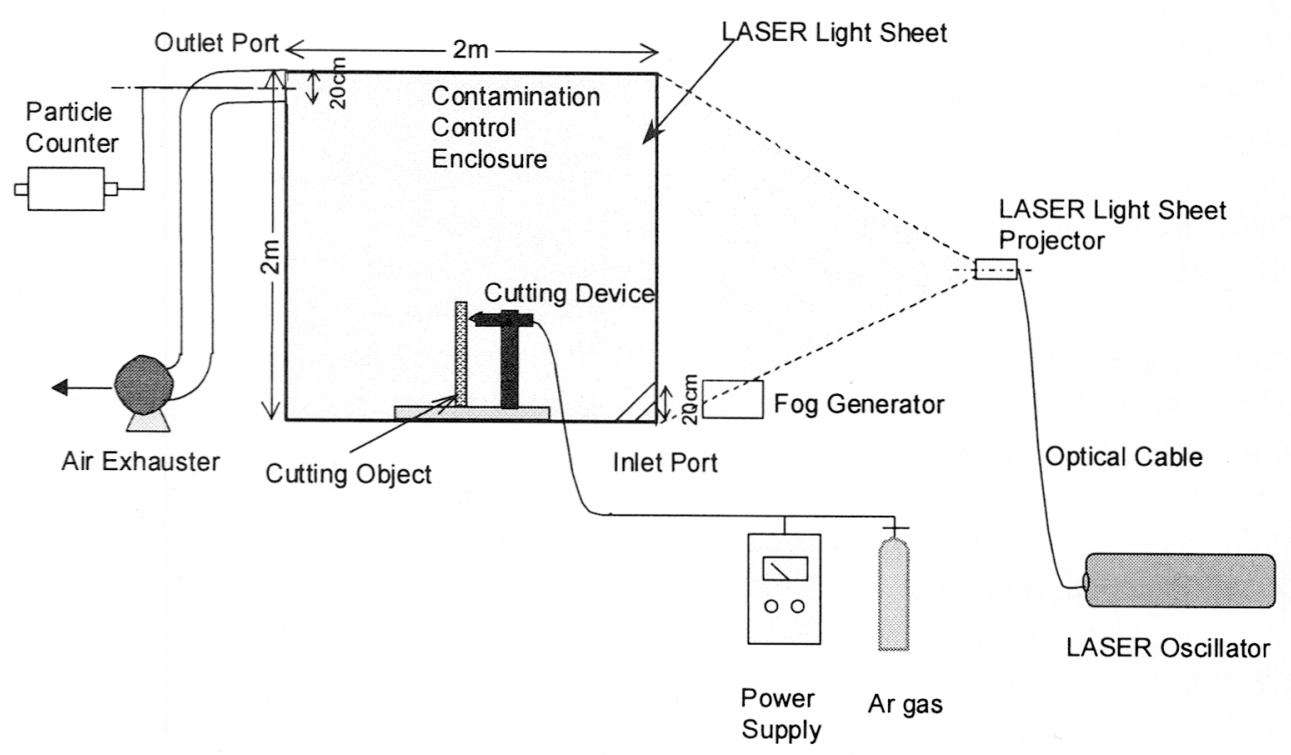

Fig. 1 Experimental Apparatus 


\section{4. エアロゾル粒子の飛散挙動解析}

プラズマアーク切断を行う場合、切断トーチ と切断対象物の間にアークが発生し、そのア一 クが金属を溶融・蒸発させる。また、ノズルよ りガスが噴出され、溶融した金属を吹き飛ばす。 トーチを適切な速度で一方向に移動させると切 断溝が形成され、切断が行われるものである。

しかし、グリーン八ウス内の飛散挙動を解析 する場合、溶融・蒸発現象まで解析対象とする ことは困難である。そこで、JPDR 解体実地試 験およびエアロゾル粒子飛散挙動試験より得ら れるエアロゾル粒子の性状及び放出挙動関連デ 一タより、エアロゾル粒子の発生条件（初期流 速、粒子径等）を入力することとした。切断開 始前より既に存在する吸排気による流動に加え、 高温ガス供給によって生じる上昇流の混在する 流れ場におけるエアロゾル粒子の運動を解く。

数值解析には 3 次元熱流動解析コード FLOW3D を使用した。本コードは、基礎方程式 の差分化に SOLA 法を採用している。連続の式、 運動量方程式、エネルギー保存式、圧縮流体を 取り扱うための状態方程式及び以下に示す質量 粒子運動方程式を解いた。

$$
\frac{d u_{p}}{d t}=g-\frac{1}{\rho} \nabla P+K_{1}\left(u-u_{p}^{\prime}\right)+K_{2}\left(u-u_{p}^{\prime}\right)\left|u-u_{p}^{\prime}\right|
$$

$u_{p}^{\prime}=u_{p}+u_{d i f}$

乱流モデルは、 $k-\varepsilon$ モデル改良型の $\mathrm{RNG}$ モデル

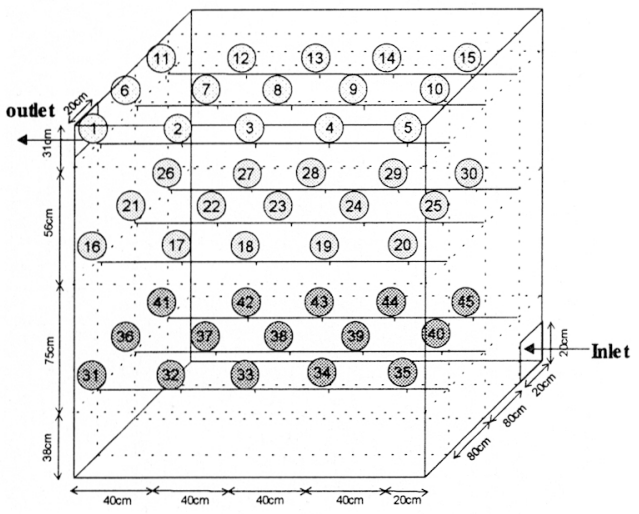

Fig. 2 Arrangement of Thermo Couples
を使用した。

\section{1 切断模擬のための仮定}

本解析で対象とする基本的体系は、既に Fig.1 で示したそれと同椂とした。グリーン八ウスに は排気口、吸気口を設け、切断架台の上に被切 断物を配置している。切断ト一チの初期位置は 被切断物の右側上部である。切断トーチはこの 位置から下方向へ移動していく。切断を模擬す るにあたり以下の仮定を設けた。

- 被切断物の熱的挙動（熱伝導・溶融等）を 無視する。

・輻射伝熱・壁との対流伝熱を無視する。

・エアロゾル粒子のミクロ的現象（例えば凝 集）については取り扱わず、質量粒子とし て運動方程式にのみ支配される。

・グリーン八ウス内壁との衝突の際には壁へ は吸着せず衝突・反射として扱う。

\section{2 切断とエアロゾル粒子発生のモデル化}

排気によって形成される流れが定常的になっ た後、時刻 $t=t_{0}$ に切断トーチ先端ノズルからプ ラズマアークを被切断物に向けて噴出させ、切 断を開始するものとした。切断を模擬するため に、Fig.3 に示すように被切断物の分割を行った。 切断セルは $y$ 方向に 1 層とし、 $x$ 方向、 $z$ 方向の

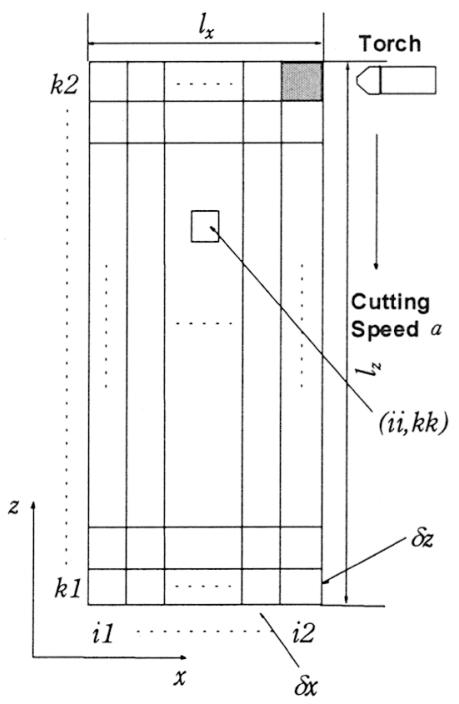

Fig. 3 Cutting Model 
矩形領域として 2 次元的に取り扱う。切断終了 時刻は $t_{0}+l_{z} / a$ と表され、また、 $\delta x_{i}, \delta z_{k}$ は被切断 物の厚さ $l_{\mathrm{x}}$, 高さ $l_{\mathrm{z}}$ と次式で関倸づけられる。

$$
\sum_{i=i 2}^{i 1} \delta x_{i}=l_{x}, \quad \sum_{k=k 2}^{k 1} \delta z_{k}=l_{z}
$$

時刻 $t_{0}$ に切断卜一チに向かい合う被切断物切断 溝の $(i 2 、 k 2)$ セルをすでに溶融吹き飛ばされたも のとして消去する。同時に、同セル内にエアロ ゾル粒子発生点を乱数計算によって設定し、セ ル内で発生するエアロゾル粒子の発生が終了す る時刻まで等時間間隔で 1 粒子ずつ放出する。

次に、時刻 $t_{0}+\delta z_{\mathrm{k} 2} / a$ には、切断トーチは( $k 2$ 1)に垂直に向かい合う点まで平行移動し、(k2-1、 i2)が消去される。被切断物上の任意のセル ( ii 、 $k k)$ が消去される時刻は次式で表される。

$t=t_{0}+\sum_{k=k k+1}^{k 2} \delta z_{k} / a+\delta z_{k k}\left(\sum_{i=i i}^{i 2} \delta x_{i}-\delta x_{i i}\right) / a l_{x}$

\section{3 解析条件}

解析体系は実験と同様で、 $2 \mathrm{~m} \times 2 \mathrm{~m} \times 2 \mathrm{~m}$ のグ リーン八ウス内においてプラズマアーク切断を 行うものとする。メッシュ数の制限からプラズ マトーチ出口径を大きくし、出口流速を下げ単 位時間あたりの投入エネルギー量を等しくした。 グリーンハウス排気量は $3.6 \mathrm{~m}^{3} / \mathrm{min}$ 、切断速度は

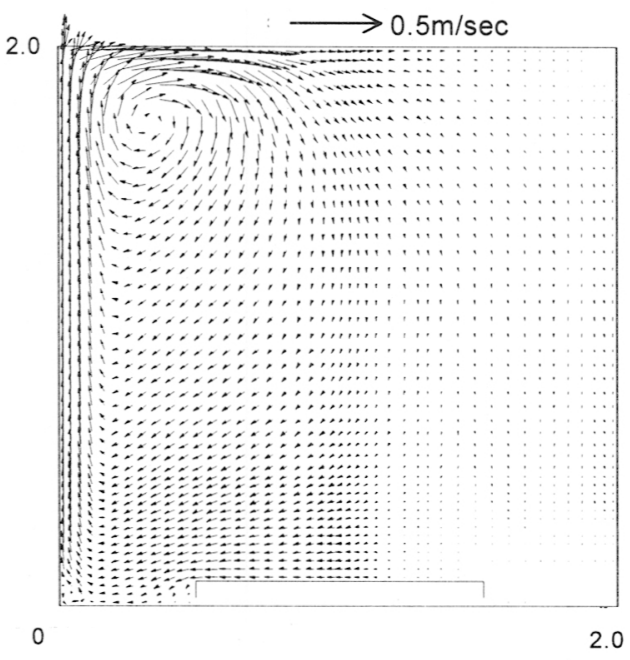

Fig. 4 Flow Vectors in Steady State
$0.3 \mathrm{~cm} / \mathrm{sec}$ 、吸排気口面積はともに $20 \mathrm{~cm} \times 20 \mathrm{~cm}$ とした。発生する粒子径を $1 \mu \mathrm{m}$ とした。

\section{5. 解析及び実験結果}

\section{1 切断前の定常状態}

Fig.4 に解析から得られた切断前の定常状態 における流速ベクトル図を示す。グリーンハウ ス前面より $0.8 \mathrm{~m}$ の断面である。床及び左壁に 沿って流速が速く、切断部周辺には速い流れが 存在しなかった。左上の天井部近傍に大規模な 渦が形成された。

次に、実験から得られた定常状態における一 連のトレーサーの可視化画像を Fig. 5 に示す。
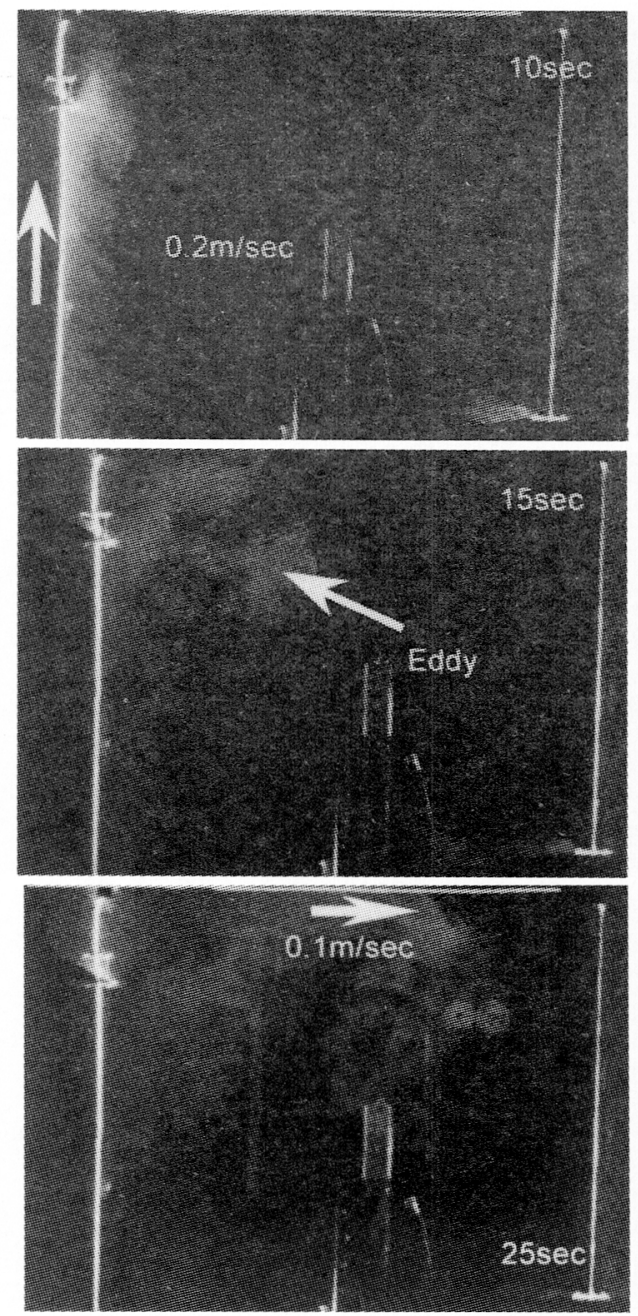

Fig. 5 Tracer Behaviors in Steady State 
吸気ロからトレーサーを開始した時点から 10 , 15,25 秒後のトレーサー挙動を示している。吸 気口から流入したトレーサーは床面に沿って左 壁面に到達した後、壁面に沿って天井部へ上昇 した。その後天井に沿って右壁面へ向かうが、 矢印で示した部分に形成されている渦に取り込 まれ、粒子群の移動速度は小さくなった。

左壁沿い及び天井を右方向へ移動する粒子群 速度、渦の形成される位置等についても解析結 果と一致し、定常状態で解析に問題のないこと が確認された。

\section{2 切断開始後のエアロゾル粒子の飛散挙動}

Fig.6 に解析で得られた切断開始後の一連の エアロゾル粒子飛散挙動を示す。切断部より発 生するエアロゾル粒子は、すぐさま上昇し直接 天井部へ達した。その後天井に沿って主に右側 及び前方の壁に向かって飛散し，18sec では多 くの粒子が右側の壁に沿って下降した。

Fig.7 に同じく解析で得られた切断時間 20 秒、 切断終了 5 秒後の温度及び流速ベクトル分布図 を示す。グリーン八ウス前面より $0.8 \mathrm{~m}$ の断面 である。高温のガスが切断部から供給され、上 昇流が形成された後、ガスの供給が終了するが、 この時点では上昇流が残存している。

同時刻、同断面において実験で得られたグリ ーン八ウス内の可視化画像を Fig. 8 亿示す。切 断終了 10 秒前にトレーサーを導入した。写真中 矢印で示すように、周囲のトレーサー濃度に比 べ濃度の薄い領域が観察された。この時点では
高温ガスの供給は終了しているが、それまで形 成されていた上昇流の形跡と考えられる。解析 結果と比較すると上昇流の形状及び位置が非常 に類似しており、切断によって生じる上昇流及 びエアロゾル粒子の飛散挙動が解析によって評 価できるものと考えられる。

さらに、実験で測定された 120 秒間切断時の 温度変化を Fig. 9 に示す。切断開始直後に天井 部左壁周辺が上昇し、最高温度部は天井部に沿 って奥面へ移動した。その後右壁に向かって最 高温度部が移動し、切断終了直前に最高で $335 \mathrm{~K}$ に達した。解析結果で得られた温度分布を同時 刻、同位置で比較すると、高温ガスが噴出され る側の切断部周辺では解析の方がわずかに高い 傾向を示していたが，その他では大きな相違は 見られなかった。

以上のように、単純な体系においては、高温 の上昇流が全体の流れを支配する体系であって も、エアロゾル粒子の飛散挙動解析が十分な精 度で可能であることが確認された。

機械的切断を模擬して解析を行った場合の切 断開始 60 秒後のエアロゾル粒子の飛散挙動を Fig.10に示す。熱の供給がないため上昇流の形 成は存在せず、エアロゾル粒子は切断部近傍に 比較的速い流れがないため切断部から徐々に周 辺へ拡散する飛散挙動を示した。

\section{3 作業環境中の空気中放射能濃度変化の評価}

内部被ばくは、放射性エアロゾル粒子の体内 摄取量として、空気中放射能濃度、作業員呼吸
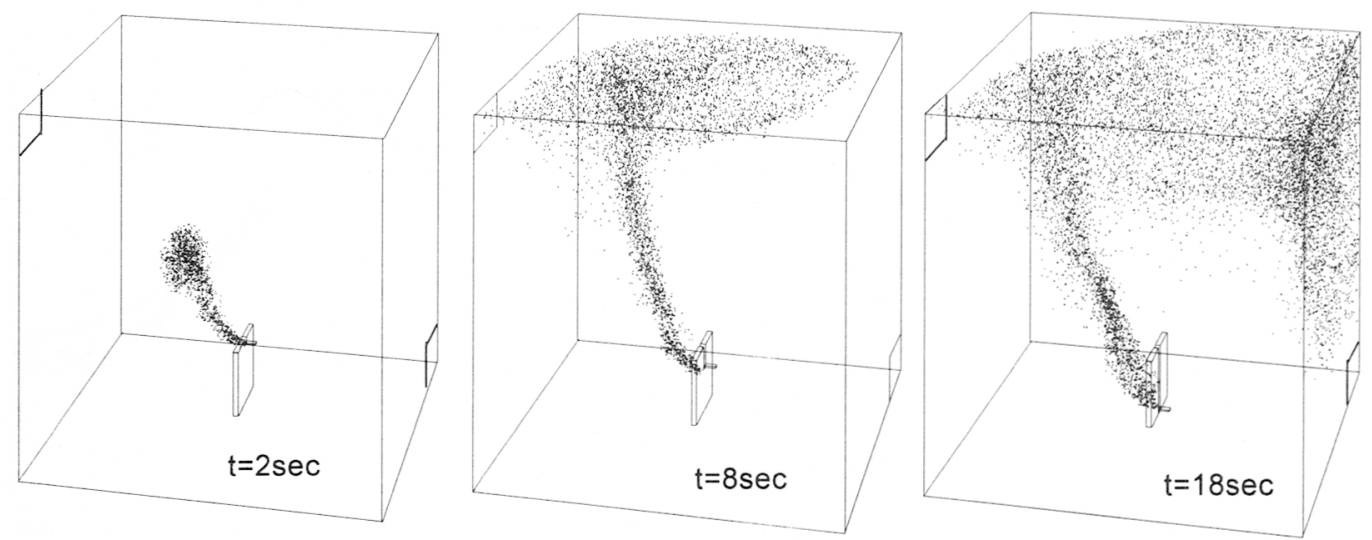

Fig. 6 Diffusion Behavior of aerosols in cutting of plasma arc 


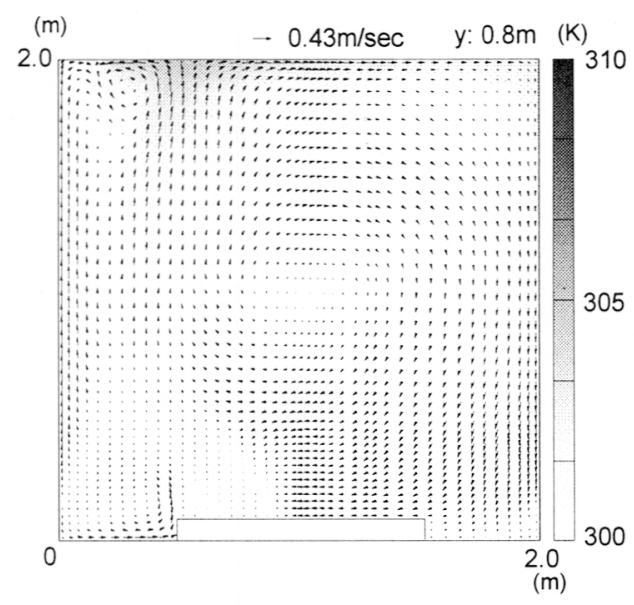

Fig. 7 Flow Vectors and Temperature Distribution

量、防護具の防護倸数等によって評価される。 呼吸量、防護係数についてはほぼ一定と見なし、 空気中放射能濃度を主要パラメータとし、時間 的及び空間的に評価することが必要である。本 検討では、エアロゾル粒子の飛散挙動に基づい た空気中放射能濃度の評価を行った。カーフ幅 $1 \mathrm{~cm}$ 、飛散率 $10^{-3}$ 、比放射能 $1.25 \times 10^{5} \mathrm{~Bq} / \mathrm{g}$ とし てエアロゾル粒子の分布から求めたグリーン八 ウスの空気中放射能濃度の時間変化を Fig.11 に示す。濃度による領域は、外部被ばくを無視 し、 ${ }^{60} \mathrm{Co}$ 単独核種が飛散したと仮定したとき、 作業員の呼吸する空気を許容量以下にするため の装備を示している。グリーンハウス中の平均 の空気中放射能濃度は、粒子群の先端が排気口 に達した時刻で上昇率が鈍るものの、切断終了 時までほぼ一定に上昇し、切断終了時に最高値 の $0.95 \times 10^{-3} \mathrm{~Bq} / \mathrm{cm}^{3}$ に達した。空間分布につい ては、Fig.6に示したようにエアロゾル粒子は局 所的に高濃度で分布する傾向にあり、排気口付 近において短時間ではあるが最高平均濃度の 3 倍程度の高い值を示した。

同様に機械的切断時についても評価を行った が、切断速度及び飛散率が $1 / 10$ 、さらに切断溝 幅が小さいことから単位時間あたりの放出量が 少なく、グリーンハウス内の空気中放射能濃度 は切断作業中 $1.0 \times 10^{-4} \mathrm{~Bq} / \mathrm{cm}^{3}$ を超えることはな く、切断方法の違いにより切断中及び直後の空 気中放射能濃度は大きく異なることも示された。

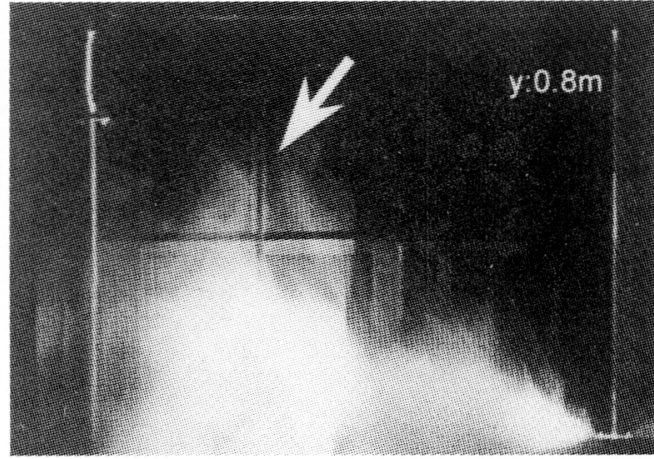

Fig. 8 Tracer Behavior after Cutting

切断作業を行うにあたり、このような飛散挙動 の解析を行い、切断対象物に対してより適切な 切断方法を選択するとともに、作業員の配置や 切断時間の設定により、より安全で効率的な解 体作業が実現される。

現在、切断作業を効率的かつ安全に進めるた めに、局所排気装置の配置やそれを含んだグリ ーン八ウスの設計の最適化に対しても寄与でき ると考えられ、検討を進めている。

\section{6. まとめ}

プラズマアークで切断する際に発生するエア ロゾル粒子の飛散挙動を数值解析によって評価 した。また、解析結果の検証のため、流れの可 視化等の実験を行い、飛散挙動を観察した。両

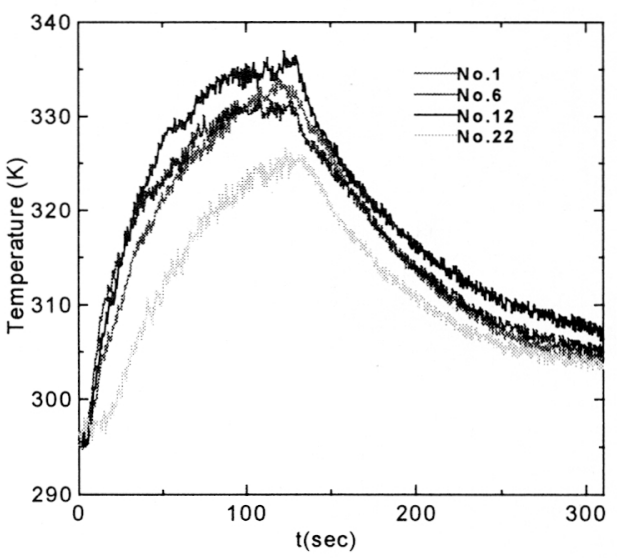

Fig. 9 Temperature Change in Transition 


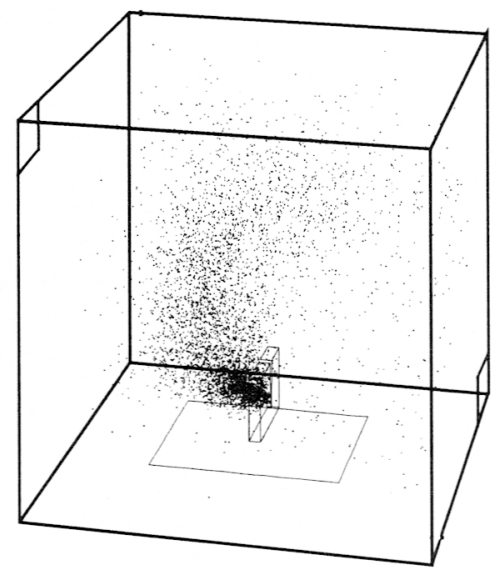

Fig. 10 Aerosol Behavior in mechanical cutting

者の結果はほぼ一致しており、エアロゾル粒子 の飛散挙動の解析が十分に可能であることが確 認された。

現在、切断作業だけでなく、コンクリートの 爆破・破砕作業等解体にかかる全作業に対して 解析できるよう作業を進めている。数值解析を 利用して、単に解体作業の安全性評価にとどま らず、解体作業を効率的に進めるために積極的 に活用する予定である。さらに、通常作業時だ けでなく、グリーン八ウスの破損等の想定事故 に対しても検討を行い、解体作業全般にわたっ て安全性を評価する手法を確立していきたい。

\section{7. おわりに}

本研究は科学技術庁の委託により行われた研 究成果の一部である。

\section{Nomenclature}

$K_{1}, K_{2} \quad$ : drag coefficients

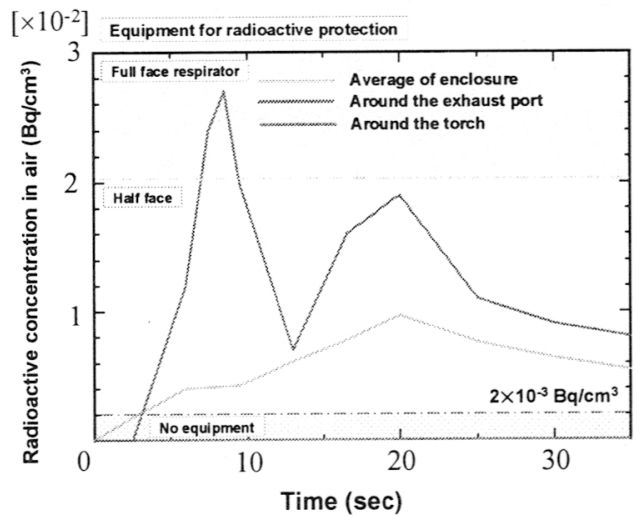

Fig. 11 Radioactive Concentration in air

$\begin{array}{ll}P & : \text { pressure } \\ a & : \text { cutting speed } \\ g & : \text { gravity } \\ t_{0} & : \text { time for start of cutting } \\ u & : \text { fluid velocity } \\ u_{\text {dif }} & : \text { particle diffusion velocity } \\ u_{\mathrm{p}} & : \text { particle velocity } \\ \rho & : \text { particle density }\end{array}$

\section{参考文献}

[1] 宮坂靖彦他、日本原子力学会誌、Vol38, No.7, (1996).

[2] 佐藤忠通、日本原子力学会誌, Vol.40, No.11, (1998).

[3] Shimada et al., Proc. of Spectrum '98, Vol. 1, 227232, Denver, (1998).

[4] Shimada et al., Proc. of 7th International Conference of Nuclear Engineering, Tokyo, (1999).

[5] J. Onodera et al., J. Aerosol Sci., Vol. 22, Suppl. 1, S747-S750, (1991). 